\title{
Local hypothermia protects the retina from ischaemic injury in vitrectomy
}

\author{
Kazushi Tamai, Eiji Toumoto, Akio Majima
}

\begin{abstract}
Aims-Hypothermic irrigating solutions were used during vitrectomy in pressure induced ischaemic eyes so that their effects on retinal function and histological changes could be investigated.

Methods-After anaesthetised albino rabbits underwent closed vitrectomy, their vitreous cavities were continuously irrigated for 30 minutes at a perfusion pressure of $140 \mathrm{~mm} \mathrm{Hg}$. The rabbits were divided into three groups according to their intraocular perfusion temperatures $-8^{\circ} \mathrm{C}, 22^{\circ} \mathrm{C}$, and $38^{\circ} \mathrm{C}$. Electroretinograms were taken before and after irrigation. Glutamate levels in the vitreous were examined after irrigation. Eyes were enucleated on the seventh postoperative day and examined histologically.

Results-On the seventh postoperative day, the recovery rate of a-wave amplitudes was significantly lower in the $38^{\circ} \mathrm{C}$ group than in the $8^{\circ} \mathrm{C}$ group, and that of b-wave amplitudes was significantly lower in the $38^{\circ} \mathrm{C}$ group than in either the $8^{\circ} \mathrm{C}$ or $22^{\circ} \mathrm{C}$ group. Retinal damage in the $38^{\circ} \mathrm{C}$ group revealed more severe histological impairment than in either the $8^{\circ} \mathrm{C}$ or $22^{\circ} \mathrm{C}$ group. Oedema of the inner retinal layer was significant in both the $22^{\circ} \mathrm{C}$ and $38^{\circ} \mathrm{C}$ groups. Glutamates reached peak values 30 minutes after the end of ischaemia in the $38^{\circ} \mathrm{C}$ group. However, no significant glutamate increases were detected 15 to 60 minutes after ischaemia in either the $8^{\circ} \mathrm{C}$ or $22^{\circ} \mathrm{C}$ group.

Conclusion-Local hypothermia during vitrectomy in acute ischaemic eyes appears to decrease retinal damage.

(Br F Ophthalmol 1997;81:789-794)
\end{abstract}

Department of

Ophthalmology,

Nagoya City University

Medical School, Japan

K Tamai

E Toumoto

A Majima

Correspondence to: Kazushi Tamai, MD Department of

Ophthalmology, Nagoya City University Medical School, 1

Kawasumi, Mizuho-cho,

Mizuho-ku, Nagoya 467,

Japan.

Accepted for publication 4 June 1997
Hypothermia is known to increase tissue tolerance to ischaemic insults, ${ }^{1}$ and has been applied in neurosurgery ${ }^{2}$ and cardiac surgery. ${ }^{3}$ Hypothermic neuroprotective properties are well documented in brain damage, ${ }^{4}$ the effects being partly due to reducing the ischaemia induced release of excitatory amino acids. ${ }^{5}$

The application of hypothermia in vitreous surgery has recently been investigated..$^{6-12}$ Hirose et $a l^{12}$ reported that chilled solutions were useful during vitreous surgery for advanced stages of retinopathy of prematurity in order to prevent or minimise fibrin formation. $\mathrm{We}^{11}$ reported in a previous paper that local hypothermia during vitrectomy reduced retinal damage in pressure induced mild ischaemia. Several factors, including excitatory amino acids and free radicals, are known to be related to retinal damage resulting from ischaemia and subsequent reperfusion. ${ }^{13-15}$ However, the mechanisms for hypothermic effects on an ischaemic retina have not yet been substantiated.

In this study, we performed intravitreous irrigation under complete vaso-occlusive pressure using solutions at various temperatures, while examining the electrophysiological and histological changes of the retina. We also measured changes in glutamate levels in the vitreous after ischaemia.

\section{Materials and methods}

VITRECTOMY AND SUBSEQUENT VITREOUS PERFUSION

Twenty five albino rabbits were anaesthetised with intravenous injections of pentobarbitone $20 \mathrm{mg} / \mathrm{kg}$. Their pupils were dilated with a $1: 1$ mixture of $0.25 \%$ tropicamide and $5 \%$ phenylephrine, and then retinal cryopexy was performed on one eye of each animal in areas where sclerotomy was planned. The animals were anaesthetised again 7 days later with intravenous injections of pentobarbitone 20 $\mathrm{mg} / \mathrm{kg}$ and intramuscular injections of ketamine hydrochloride $5 \mathrm{mg} / \mathrm{kg}$. The pupils were dilated once again and conjunctival peritomy was performed. A $500 \mathrm{ml}$ bottle of intraocular irrigating solution (BSS plus, Alcon, Fort Worth, TX, USA) was suspended about 100 $\mathrm{cm}$ above eye level, and connected to a 20 gauge infusion cannula through a $400 \mathrm{~cm}$ long tube. The cannula was inserted through the sclerotomy in the inferonasal quadrant $4 \mathrm{~mm}$ posterior to the limbus, and sutured in place. The rabbits were divided into three groups (seven animals each) according to the temperatures of the irrigating solutions $-8^{\circ} \mathrm{C}, 22^{\circ} \mathrm{C}$ (room temperature), and $38^{\circ} \mathrm{C}$ (body temperature). The temperature of $8^{\circ} \mathrm{C}$ was constantly maintained by passing the fluid through a tube immersed in iced water. A vitreous cutter (MVS XX, Alcon) was placed through the sclerotomy in the supratemporal quadrant, and vitrectomy was then performed for 7 minutes. Adequate illumination was provided by a paraxial light operation microscope without using intraocular fibreoptic illumination. After the vitrectomy was completed, the cutter was replaced by a 20 gauge cannula connected to a peristaltic aspiration pump (TMP-15E, Toyoseisakusho, Japan). Perfusion pressures were measured with pressure transducers attached to both the inflow and outflow cannulas. The 


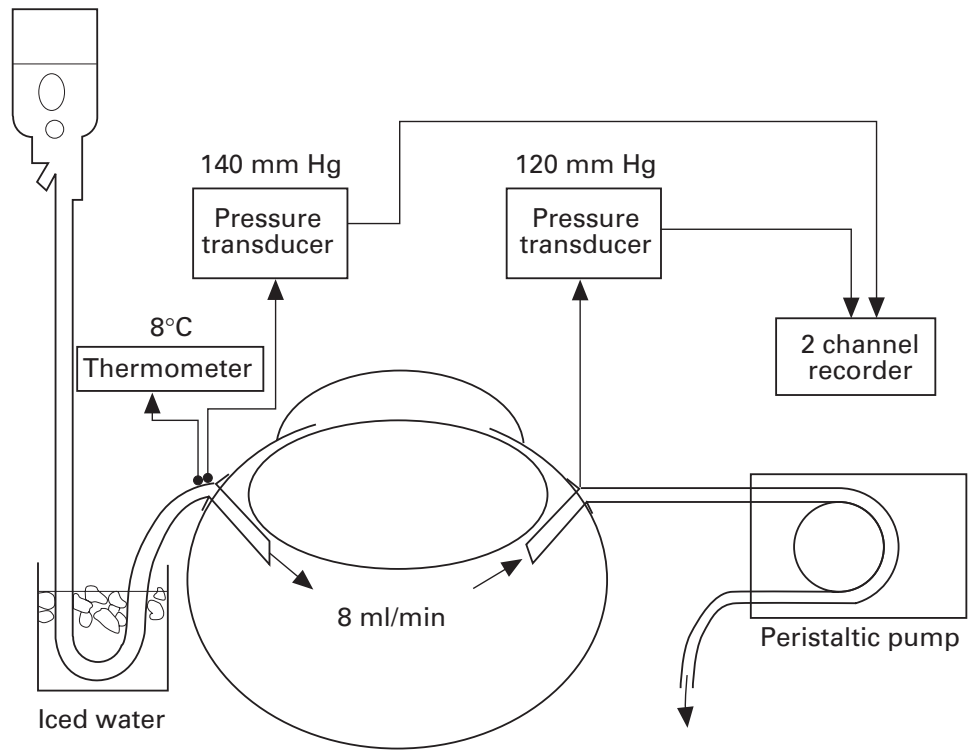

Figure 1 The vitreous cavity is irrigated at perfusion pressure of $140 \mathrm{~mm} \mathrm{Hg}$. The pressure at the outflow site is maintained at about $120 \mathrm{~mm} \mathrm{Hg}$.

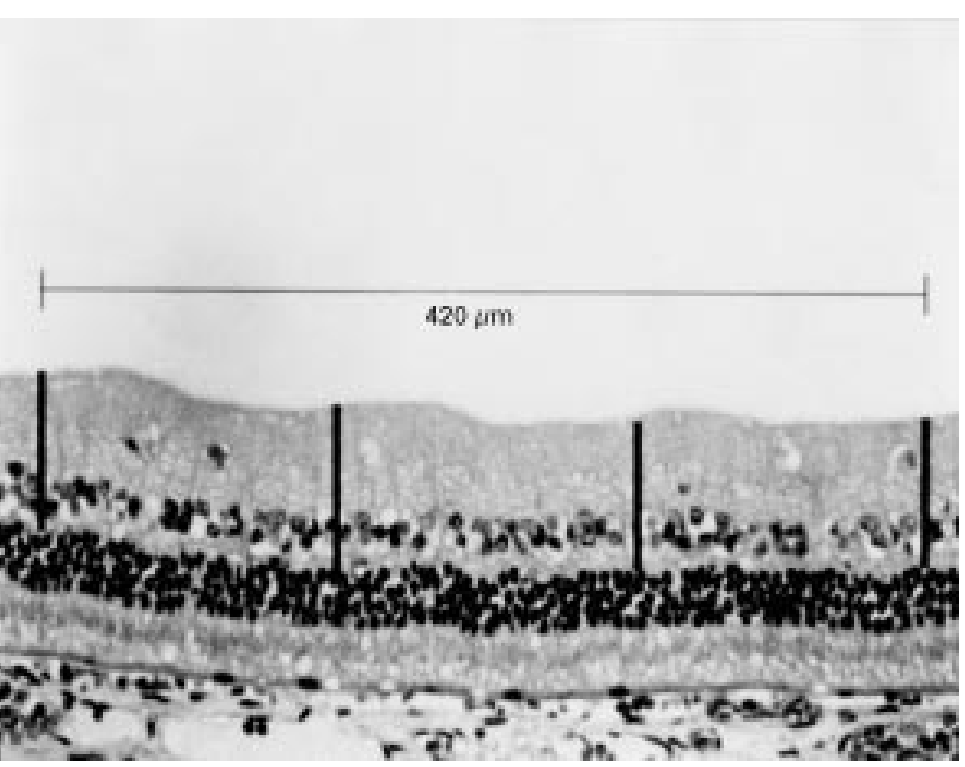

Figure 2 A sample for the evaluation of inner retinal layer (IRL) thickness, a region with a width of $420 \mu \mathrm{m}$ at a distance of $6.0 \mathrm{~mm}$ from the ora serrata. The IRL thickness was measured and averaged from four values in each region. Vertical bars indicate IRL thickness.
Table 1 Grading of retinal damage

\begin{tabular}{ll}
\hline Grade 0 & $\begin{array}{l}\text { No definite abnormal findings } \\
\text { Mildly impaired regions such as } \\
\text { vacuolation of the photoreceptor cells }\end{array}$ \\
Frade 2 & $\begin{array}{l}\text { Focal oedema, inflammatory cell } \\
\text { infiltration, and/or proliferation of the } \\
\text { retinal pigment epithelium }\end{array}$ \\
Exudative retinal detachment and/or \\
Grade 3 $(\mathrm{a}, \mathrm{b})$ & $\begin{array}{l}\text { Totaption of the photoreceptor cells } \\
\text { layer }\end{array}$ \\
Grade 4(a, b) &
\end{tabular}

a, without disorganisation of the inner retinal layer.

$\mathrm{b}$, with disorganisation of the inner retinal layer.

excluded from the experiment because of complications arising from surgical proceduretwo for vitreous haemorrhage and two for lens injury.

ELECTRORETINOGRAMS (ERGS)

ERG responses were measured after 40 minutes of dark adaptation using a recording device (PE-300, Tomey, Nagoya, Japan) before and 2 hours after surgery. This procedure was repeated on the first and seventh days postoperatively. ERGs were recorded by positioning the rabbits in a box and placing a xenon lamp $15 \mathrm{~cm}$ in front of the eye. A flash of maximum intensity $(20 \mathrm{~J})$ provided photostimulation. A contact lens electrode was placed on the cornea, and a reference electrode subcutaneously at the vertex. ERGs were taken of both eyes for each animal. The a- and b-wave amplitudes of each operated eye were shown as a percentage of those in its matching nonoperated eye.

\section{HISTOLOGICAL EVALUATION}

Both eyes of each animal were enucleated on the seventh postoperative day, and fixed with a $1: 1$ mixture of $2.5 \%$ glutaraldehyde and $5 \%$ formaldehyde in $0.1 \mathrm{M}$ phosphate buffer $(\mathrm{pH}$ 7.2). After fixation, the eyes were cut in half and embedded in paraffin. Sagittal sections of $2.5 \mu \mathrm{m}$ thickness were then sliced at or near the optic disc and stained with haematoxylin and eosin. Five different sections were selected at random from each eye, and examined by light microscopy. After analysing the entire retina in each section, we categorised the sections into the grades according to tissue damage (Table 1). Each section's grade was determined by the highest degree of damage found in it. If there were two or more differently graded regions of damage, the severest grade was chosen to represent the section. The evaluation of the inner retinal layer (IRL) oedema was based upon its mean thickness in all the sections except for those with disorganisation of IRL (grade 3(b) or $4(\mathrm{~b})$ ). The two regions (with a width of 420 $\mu \mathrm{m})$ at distances of 6.0 and $10.0 \mathrm{~mm}$ from the ora serrata of each side were sampled, giving a total of four regions in each section. Each region was examined by light microscopy, and then photomicrographed. Colour slides (35 $\mathrm{mm}$ ) were scanned with a LS-20E (Nikon, Tokyo, Japan), and saved to the hard disk of a Compaq computer (Prolinea 5100). The measurement of IRL thickness (from the outer plexiform layer to the inner limiting membrane) was made directly on the 19 inch monimycin ointment were applied daily in the cul de sac for 7 days after surgery. Four animals were 

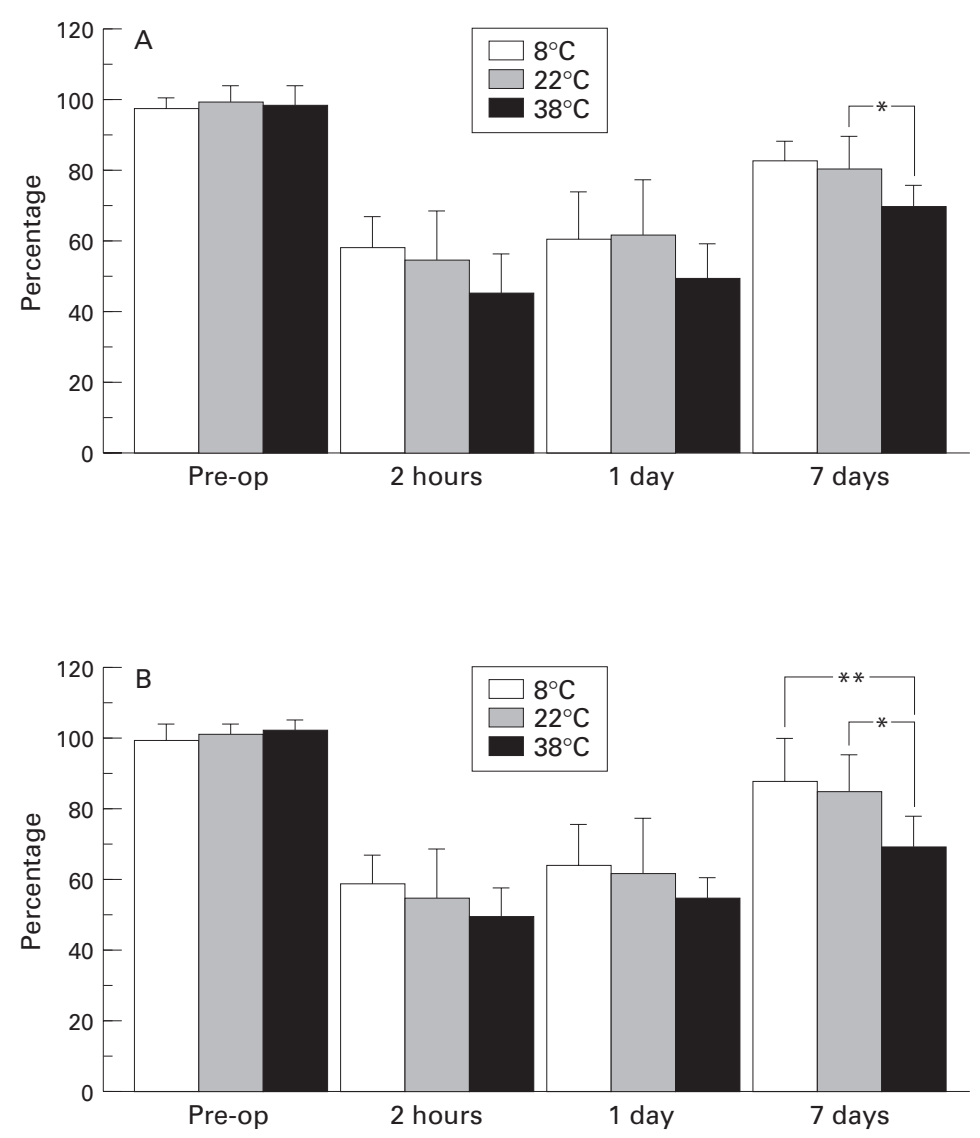

Figure 3 Relative ERG recovery of a-wave $(A)$ and b-wave (B) amplitudes $(n=7)$. ${ }^{*} p<0.05,{ }^{\star *} p<0.01$. Error bars represent standard deviations.

tor display image using Adobe Photoshop (Adobe systems, Mountain View, CA, USA) and Window draw (Micrografix, Richardson, TX, USA). Four values were taken from the left to right margin for each $140 \mu \mathrm{m}$ of wide strip in a region, and were averaged to obtain a single value (Fig 2). Then, a single average figure was calculated from values for four regions in each section. Masked authors (KT, ET) categorised retinal damage and measured IRL thickness, finding a variance less than $5 \%$.

\section{MEASUREMENT OF GLUTAMATE IN VITREOUS}

FLUID

Another set of 45 rabbits were anaesthetised, and vitrectomy and intravitreous perfusion were done on one eye of each animal under an infusion pressure of $140 \mathrm{~mm} \mathrm{Hg}$ for 30 minutes in the same manner described above. The rabbits were divided into three groups (15 animals each) according to irrigating solution temperatures $\left(8^{\circ} \mathrm{C}, 22^{\circ} \mathrm{C}\right.$, and $\left.38^{\circ} \mathrm{C}\right)$. A 29 gauge needle was inserted through the nonvascular pars plana into the vitreous, and 0.4 $\mathrm{ml}$ of vitreous fluid was extracted after ischaemia. Each temperature group was divided into three subgroups (five animals each) according to their respective extraction times of 15,30 , and 60 minutes after ischaemia. The vitreous fluid was taken only once from each animal in order to avoid the injurious effects of the extraction. Fluids were immediately frozen at $-20^{\circ} \mathrm{C}$, then analysed for amino acids by high performance liquid chromatography (HPLC)
Table 2 Distribution of retinal damage in each grade. Five randomly chosen sections from each eye are categorised into four grades $(n=35)$

(A) Perfusion at $8^{\circ} \mathrm{C}$

\begin{tabular}{lllllll}
\hline \multirow{5}{*}{ Eyes } & \multicolumn{2}{l}{ Grade } & & & \\
\cline { 2 - 7 } & 1 & 2 & $3(a)$ & $3(b)$ & $4(a)$ & $4(b)$ \\
\hline 1 & 3 & 2 & 0 & 0 & 0 & 0 \\
2 & 3 & 2 & 0 & 0 & 0 & 0 \\
3 & 4 & 1 & 0 & 0 & 0 & 0 \\
4 & 3 & 2 & 0 & 0 & 0 & 0 \\
5 & 2 & 2 & 1 & 0 & 0 & 0 \\
6 & 2 & 2 & 1 & 0 & 0 & 0 \\
7 & 1 & 3 & 1 & 0 & 0 & 0 \\
Total & 18 & 14 & 3 & 0 & 0 & 0 \\
\hline
\end{tabular}

(B) Perfusion at $22^{\circ} \mathrm{C}$

\begin{tabular}{lllllll}
\hline \multirow{5}{*}{ Eyes } & 1 & 2 & $3(a)$ & $3(b)$ & $4(a)$ & $4(b)$ \\
\cline { 2 - 7 } & 3 & 2 & 0 & 0 & 0 & 0 \\
1 & 3 & 2 & 0 & 0 & 0 & 0 \\
2 & 1 & 3 & 1 & 0 & 0 & 0 \\
3 & 1 & 2 & 2 & 0 & 0 & 0 \\
4 & 2 & 1 & 2 & 0 & 0 & 0 \\
5 & 3 & 2 & 0 & 0 & 0 & 0 \\
6 & 0 & 1 & 3 & 0 & 1 & 0 \\
7 & 13 & 13 & 8 & 0 & 1 & 0 \\
\hline
\end{tabular}

(C) Perfusion at $38^{\circ} \mathrm{C}$

\begin{tabular}{lllllll}
\hline \multirow{5}{*}{ Eyes } & \multicolumn{2}{l}{ Grade } & & & & \\
\cline { 2 - 6 } & 1 & 2 & $3(a)$ & $3(b)$ & $4(a)$ & $4(b)$ \\
\hline 1 & 0 & 0 & 4 & 0 & 1 & 0 \\
2 & 0 & 0 & 2 & 1 & 1 & 1 \\
3 & 0 & 1 & 3 & 0 & 1 & 0 \\
4 & 0 & 0 & 2 & 0 & 1 & 2 \\
5 & 0 & 0 & 2 & 0 & 2 & 1 \\
6 & 0 & 1 & 2 & 0 & 2 & 0 \\
7 & 0 & 0 & 3 & 1 & 1 & 0 \\
Total & 0 & 2 & 18 & 2 & 9 & 4 \\
\end{tabular}

using the L-8500 (Hitachi Seisakusho, Japan). Collected samples were thawed within a few days after extraction, derivatised using sulphosalicylic acid as an internal standard, and then centrifuged for 10 minutes at $12800 \mathrm{~g}$. Supernatant portions were removed and their $\mathrm{pH}$ was adjusted to 1.6 with hydrochloric acid and lithium hydroxide. These samples were suffused directly onto an HPLC column (internal diameter $60 \mathrm{~mm} \times 4.6 \mathrm{~mm}$ ) containing spherical particles of $3 \mu \mathrm{m}$. Amino acids separated on the column were reacted with ninhydrin, and then visualised by spectrophotometric detection under wavelengths of $440 \mathrm{~nm}$ and $570 \mathrm{~nm}$. Glutamate concentrations were estimated by peak heights and compared with standard samples. Serine concentrations were also measured as a control.

All investigations involving animals conformed to the Association for Research in Vision and Ophthalmology Resolution on the Use of Animals in Research.

Statistical analysis employed the Wilcoxon signed rank test (ERGs and glutamate levels), Student's $t$ test (IRL thickness), and $\chi^{2}$ test (histological grading). A $\mathrm{p}$ value of less than 0.05 was regarded as significant.

\section{Results}

ERGS

The preoperative a-wave and b-wave amplitudes in the operated eyes averaged 115.4 (SD 32.6) $\mu \mathrm{V}$ and 230.6 (39.1) $\mu \mathrm{V}$, respectively. 

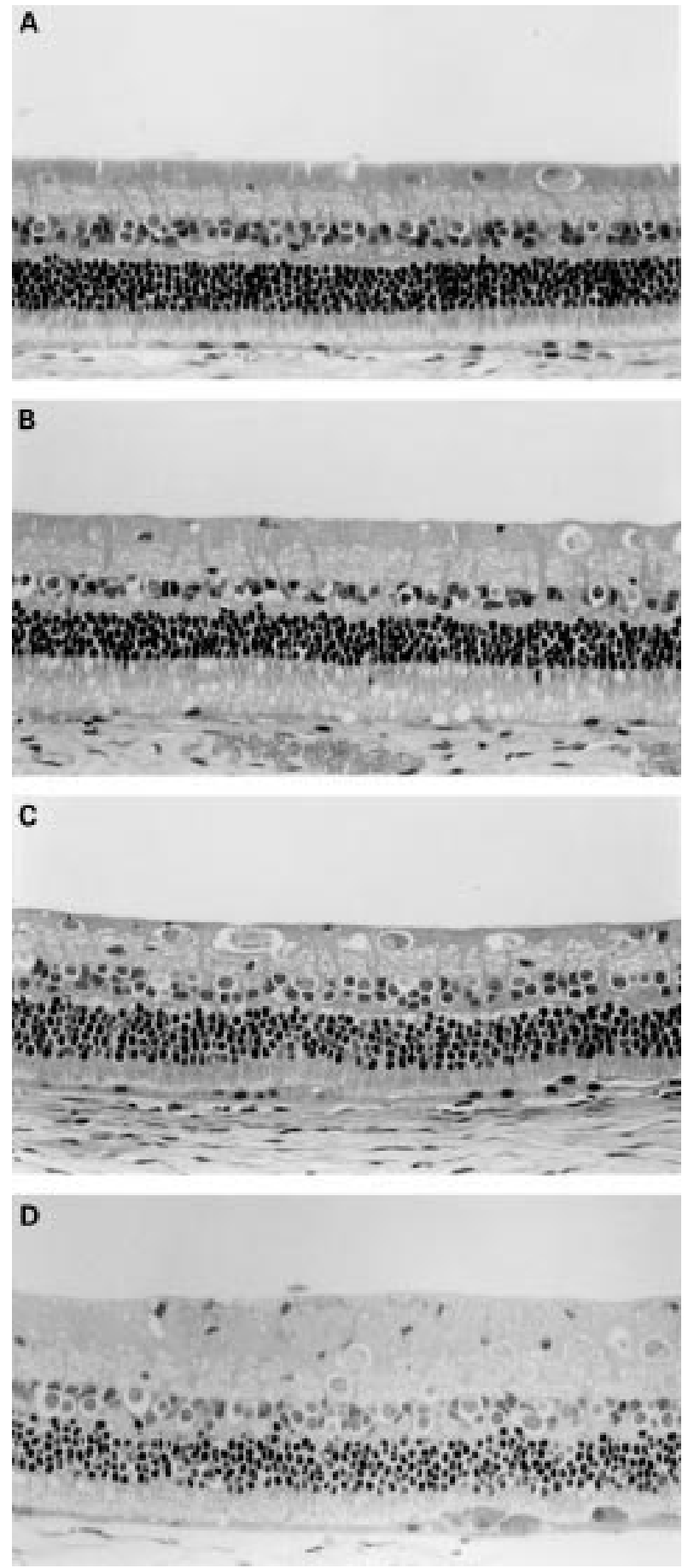
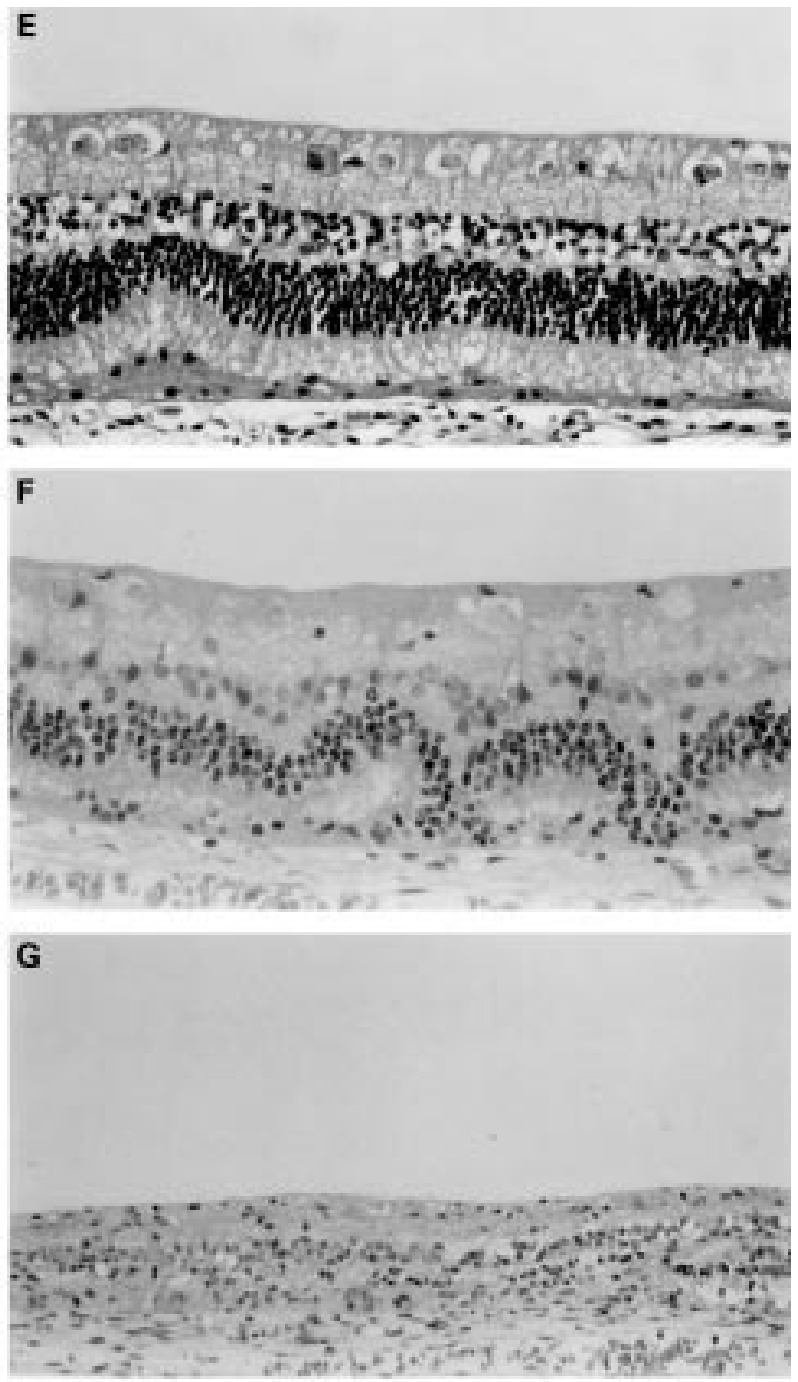

Figure 4 Histological findings of retinal damage by grade (haematoxylin and eosin stained, $\times 240$ ). (A) Grade 0 . Retina of a non-operated eye. (B) Grade 1. Retina that underwent $8^{\circ} \mathrm{C}$ irrigation. (C) Grade 2. Retina that underwent $8^{\circ} \mathrm{C}$ irrigation. Proliferation of retinal pigment epithelial cells is observed. (D) Grade 2. Retina that underwent $22^{\circ} \mathrm{C}$ irrigation.

Retinal oedema with inflammatory cell infiltration is observed. (E) Grade $3(a)$. Retina that underwent $22^{\circ} \mathrm{C}$ irrigation. $(F)$ Grade $4(a)$. Retina that underwent $38^{\circ} \mathrm{C}$ irrigation. (G) Grade 4(b). Retina that underwent $38^{\circ} \mathrm{C}$ irrigation. Retina is extensively disorganised and thinned.
Corresponding figures in the non-operated eyes were 120.6 (35.1) $\mu \mathrm{V}$ and 236.7 (34.6) $\mu \mathrm{V}$. The recoveries of a-wave and b-wave amplitudes are shown in Figure 3. On the seventh postoperative day, the a-wave amplitude percentage in the eyes perfused at $8^{\circ} \mathrm{C}, 22^{\circ} \mathrm{C}$, and $38^{\circ} \mathrm{C}$ was $82.6 \%$ (SD $5.2 \%$ ), $80.6 \%$ (11.2\%), and $70.0 \%(7.1 \%)$, respectively, compared with fellow eyes. The b-wave amplitude percentage was $87.4 \% \quad(11.7 \%), 85.0 \%$ $(9.2 \%)$, and $69.7 \%(8.8 \%)$, respectively. The recovery rate of a-wave amplitude in the eyes perfused at $8^{\circ} \mathrm{C}$ was significantly higher than at $38^{\circ} \mathrm{C}$. The recovery rate of b-wave amplitude in the eyes perfused at either $8^{\circ} \mathrm{C}$ or $22^{\circ} \mathrm{C}$ was significantly higher than at $38^{\circ} \mathrm{C}$. There were no significant differences in the recovery rates of either a- or b-wave amplitude between the $8^{\circ} \mathrm{C}$ and $22^{\circ} \mathrm{C}$ groups. Both a- and b-wave amplitudes in the non-operated eyes were stable; essentially equal before and after the surgery.

HISTOLOGICAL FINDINGS

Retinal damage was observed in all the operated eyes (Fig 4, Table 2). In each section, the severity of retinal damage was different from region to region. The majority of the sections in the eyes perfused at $38^{\circ} \mathrm{C}$ had severe retinal damage. In four sections in the $38^{\circ} \mathrm{C}$ 


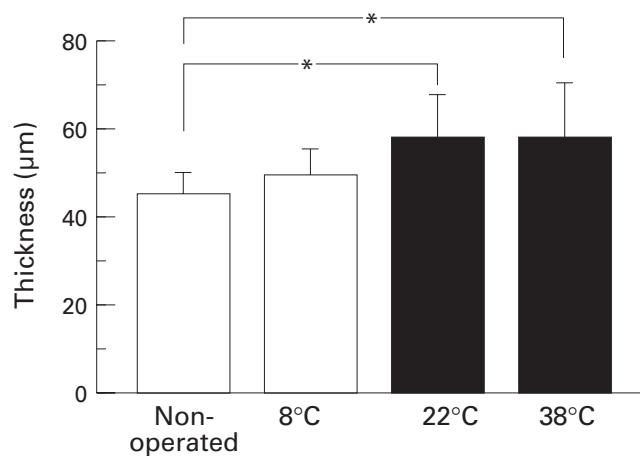

Figure 5 The thickness of inner retinal layer (IRL). Perfusion at $8^{\circ} \mathrm{C}(n=35)$, perfusion at $22^{\circ} \mathrm{C}(n=35)$, and perfusion at $38^{\circ} \mathrm{C}(n=29)$ (non-operated eyes; $\left.n=105\right)$. ${ }^{\star} p<0.01$. Error bars represent standard deviations.

group, the retina was entirely disorganised and thinned (grade 4(b)), although only one section in the $22^{\circ} \mathrm{C}$ group had total disruption of the outer retinal layer (grade $4(\mathrm{a})$ ). None of the $8^{\circ} \mathrm{C}$ group exhibited a grade more severe than 3(a). The proportion of grades 3 and 4 was significantly more frequent in the eyes perfused at $38^{\circ} \mathrm{C}$ than in those perfused at either $8^{\circ} \mathrm{C}$ or $22^{\circ} \mathrm{C}(\mathrm{p}<0.01)$. All non-operated eyes were categorised as grade 0 . The thickness of IRL in the non-operated (control), $8^{\circ} \mathrm{C}, 22^{\circ} \mathrm{C}$, and $38^{\circ} \mathrm{C}$ groups was $45.6(3.8) \mu \mathrm{m}, 49.2$ (5.6) $\mu \mathrm{m}, 58.2$ (9.4) $\mu \mathrm{m}$, and 57.9 (11.4) $\mu \mathrm{m}$, respectively (Fig 5). The IRL thickness was significantly larger in both the $22^{\circ} \mathrm{C}$ and $38^{\circ} \mathrm{C}$ groups $(\mathrm{p}<0.01)$, whereas no significant differences were found between the $8^{\circ} \mathrm{C}$ group and non-operated eyes.

\section{GLUTAMATE LEVEL IN THE VITREOUS AFTER} ISCHAEMIA

Results are summarised in Figure 6. In the $38^{\circ} \mathrm{C}$ group, the glutamate level at 30 minutes was $35.3(14.7) \mu \mathrm{mol} / \mathrm{ml}$, which was significantly higher than the $5.9(4.9) \mu \mathrm{mol} / \mathrm{ml}$ in the $8^{\circ} \mathrm{C}$ group and $7.0(3.6) \mu \mathrm{mol} / \mathrm{ml}$ in the $22^{\circ} \mathrm{C}$
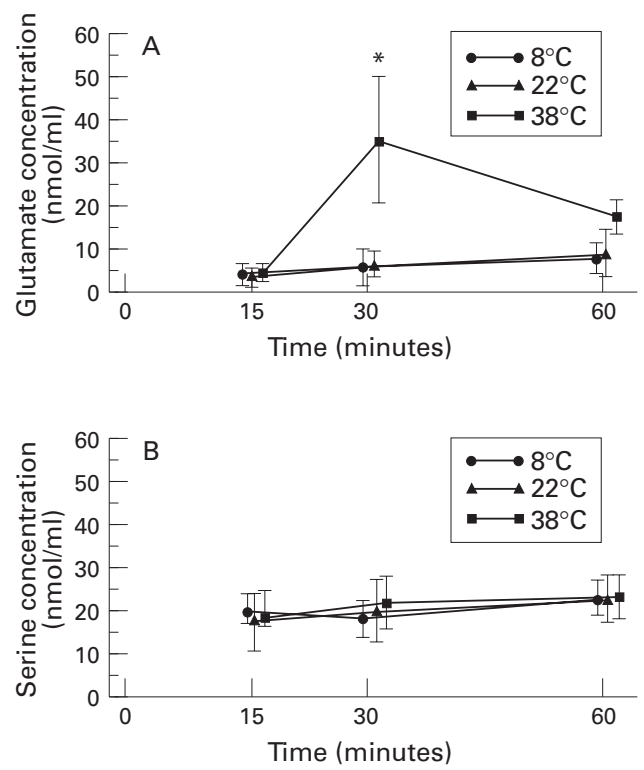

Figure 6 Changes in glutamate $(A)$ and serine (B) levels in the vitreous after ischaemia $(n=5) .{ }^{\star} p<0.01$. Error bars represent standard deviations. group ( $\mathrm{p}<0.01$ ). No significant glutamate level changes were detected 15 to 60 minutes after ischaemia in either the 8 or $22^{\circ} \mathrm{C}$ group. Serine levels showed no significant changes 15 to 60 minutes after ischaemia in any of the three groups.

The rectal temperature of all animals used averaged $38.4(1.0)^{\circ} \mathrm{C}$ throughout the experiments.

\section{Discussion}

$\mathrm{We}^{11}$ reported, in a previous paper, that histological retinal damage was more severe in the $38^{\circ} \mathrm{C}$ perfusion group compared with the $22^{\circ} \mathrm{C}$ or $8^{\circ} \mathrm{C}$ perfusion groups under relatively mild ischaemia produced by $70 \mathrm{~mm} \mathrm{Hg}$ of perfusion pressure. The present experiment showed more clearly that the $38^{\circ} \mathrm{C}$ group suffered more severe retinal impairment than the other two groups in both ERGs and histological findings under complete vaso-occlusive ischaemia. Furthermore, we confirmed that only the $8^{\circ} \mathrm{C}$ group suffered no significant inner retinal oedema. These results showed that local hypothermia protects the retina more effectively when the ischaemia is more serious. In this study, grading was mainly according to outer retinal layer (ORL) impairment, because morphological injury of ORL was more evident than that of IRL in the majority of the damaged regions. Only in the sections of marked ORL damage (grades 3 and 4), was disorganisation of IRL observed. This is probably due to abundant glycogen at the inner layer of the rabbits' poorly vascularised retina. ${ }^{16}$ In ischaemia, glycolysis proceeds anaerobically, ${ }^{17}$ and the inner layer of rabbit eyes is considered to be more ischaemia tolerant than the outer layer.

Glutamates act as a mediator of neural injury in ischaemic conditions, ${ }^{18}$ and extracellular glutamates were found to have increased in ischaemic brains ${ }^{5}$ and spinal cords. ${ }^{19}$ Glutamate increase in the extracellular space of the ischaemic retina has recently been well demonstrated in vivo using the microdialysis technique. ${ }^{14}$ In our experiment, glutamates released from the retina into the vitreous immediately flowed away from the outflow site during ischaemia, and the glutamates reached their peak level after they were dispersed into the vitreous following the end of ischaemia. One must consider the possible influence of the breakdown of the blood-aqueous barrier resulting in increased glutamates in the vitreous, owing to high levels of amino acids in the plasma. ${ }^{20}$ However, since the levels of serine, one of the non-neurotransmitter amino acids, showed no significant changes 15 to 60 minutes after the ischaemia in any of the three groups, the significant increase of glutamate levels in the $38^{\circ} \mathrm{C}$ group was thought to be primarily due to ischaemic injury.

Evidence that some of the neuroprotective effects of hypothermia may result from reducing ischaemia induced release of excitatory amino acids has recently been revealed. ${ }^{4}$ It is suggested that only a few degrees of hypothermia during ischaemia confer a marked cerebral protective effect ${ }^{4}$ and limit glutamate excitoxity 
by decreasing the release of glutamate during cerebral ischaemia. ${ }^{5}$ In one ${ }^{9}$ of our previous publications, we found that retinal temperature decreased by about $9^{\circ} \mathrm{C}$ when the vitreous was irrigated with a $22^{\circ} \mathrm{C}$ solution. The present results indicated that $22^{\circ} \mathrm{C}$ seemed to be low enough to protect the retina from ischaemic injury related to glutamate release. The histological findings, however, showed significant retinal oedema in the $22^{\circ} \mathrm{C}$ group, which was not seen in the $8^{\circ} \mathrm{C}$ group. This suggested that other mechanisms, such as decreased production of free radicals, preservation of energy resources, and reduced toxic metabolised wastes may have worked more efficiently in the $8^{\circ} \mathrm{C}$ group than in the $22^{\circ} \mathrm{C}$ group.

Various kinds of neuroprotective agents, including glutamate receptor antagonists ${ }^{21}$ and antioxidant enzymes, ${ }^{22}$ have proved to be effective in reducing experimentally induced ischaemic injury. However, these agents should only be applied to human eyes with caution, because glutamate is an indispensable neurotransmitter, and total inhibition of its role seems to be harmful to retinal function. Moreover, some of these agents are reported to have anaesthetic properties which can impair memory and cognitive function long after administration. ${ }^{23}$ Local hypothermia may be more effective than the above applications because of its minimal side effects.

Many disorders requiring vitreous surgery are considered to have ischaemic conditions such as diabetes mellitus and retinal vessel occlusion. Since intraocular bleeding is one of the common complications during vitreous surgery, an irrigation bottle is often elevated in order to reduce it. ${ }^{24}$ This procedure, however, produces further ischaemic conditions in the operated eyes. Therefore, finding an effective means for reducing retinal damage from ischaemia becomes a key concern in vitreous surgery. $\mathrm{We}^{9}$ reported that local hypothermia during vitrectomy under normal pressure for 60 minutes significantly inhibited the breakdown of the blood-aqueous barrier. This effect, however, was not found in a short term irrigation of 30 minutes. ${ }^{9} \mathrm{We}^{10}$ also examined bleeding time and postoperative inflammation by injuring the retinal artery during vitrectomy, and confirmed that hypothermia reduced both intraocular bleeding and postoperative inflammation. Summing up the results of the present experiments, we consider hypothermia to be effective in prolonged or complicated surgery where intraocular bleeding is expected and/or ischaemia is evident. Keeping in mind that our experiments were conducted using only three different temperatures, the degree to which the temperature of irrigating solutions should be lowered could not be determined accurately. Extreme cooling should be avoided because Zilis et $a l^{8}$ reported that $2^{\circ} \mathrm{C}$ fluid caused sub- clinical retinal detachment, which was not observed when $22^{\circ} \mathrm{C}$ fluid was used. We are planning to investigate further the optimal temperature and conditions for applying hypothermia during vitreous surgery.

1 Hirsch H, Bolte A, Schandig A, Töniss D. Über die Wiederbelebung des Gehirns bei Hypothermie. Pfügers Arch 1957;265:328-36.

2 McDowall DG. The current usage of hypothermia in British neurosurgery. Br $\mathcal{F}$ Anaesth 1971;43:1084-7.

3 Lewis FJ, Taufic M, Minn M. Closure of atrial septal defects with the aid of hypothermia; experimental accomplishment and the report of one successful case. Surgery 1953;33:529.

4 Busto R, Dietrich WD, Globus MY, Valdés I, Scheinberg P, Ginsberg MD. Small differences in intraischemic brain temperature critically determine the extent of ischemic neuronal injury. F Cereb Blood Flow Metabol 1987;7:72938.

5 Baker CJ, Fiore AJ, Frazzini VI, Choudhri TF, Zubay GP, Solomon RA. Intraischemic hypothermia decreases the release of glutamate in the cores of permanent focal release of glutamate in the cores of permanent
cerebral infarcts. Neurosurgery 1995;36:994-1002.

6 Rinkoff J, Machemer R, Hida T, Chandler D. Temperaturedependent light damage to the retina. Am $\mathcal{f}$ Ophthalmol 1986;102:452-62.

7 Jabbour NM, Schepens CL, Buzney SM. Local ocular hypothermia in experimental intraocular surgery. Ophthalmology 1988;95:1687-90.

8 Zilis JD, Chandler D, Machemer R. Clinical and histologic effects of extreme intraocular hypothermia. Am f Ophthalmol 1990;109:469-73.

9 Tamai K, Majima A, Yan C. Effects of local hypothermia on uveal blood flow and postoperative inflammation in vitrectomy. Fpn f Ophthalmol 1995;39:43-8.

10 Tamai K, Majima A. The use of hypothermia to control hemorrhage during vitrectomy. Folia Ophthalmol fpn 1995; 46:38-42.

11 Tamai K, Toumoto E. Effects of local hypothermia on ischemic eyes in vitrectomy. Fpn F Ophthalmol 1996;40 $220-8$

12 Hirose T, Schepens CL, Katsumi O, Mehta MC. Open-sky vitrectomy for severe retinal detachment caused by advanced retinopathy of prematurity. In: Flynn JT, Tasman W, eds. Retinopathy of prematurity. New York: SpringerVerlag, 1992:95-114

13 Delbarre G, Delbarre B, Calinon F, Ferger A. Accumulation of amino acids and hydroxyl free radicals in brain and retina of gerbil after transient ischemia. F Ocular Pharm 1991;7:147-55.

14 Louzada-Junior P, Dias JJ, Santos WF, Lachat JJ, Bradford HF, Coutinho-Netto J. Glutamate release in experimental ischaemia of the retina: an approach using microdialysis. $\mathcal{F}$ Neurochem 1992;59:358-63.

15 Neal MJ, Cunningham JR, Hutson PH, Hogg J. Effects of schaemia on neurotransmitter release from the isolated retina. F Neurochem 1994;62:1025-33.

16 Kuwahara T, Cogan DG. Retinal glycogen. Arch Ophthalmol 1961;66:96-104.

17 Weiss $\mathrm{H}$. The carbolhydrate reserve in the vitreous body and retina of the rabbit's eye during and after pressure schaemia and insulin hypoglycaemia. Ophthalmic Res 1972;1:360-71.

18 Choi DW. Glutamate neurotoxity and diseases of the nervous system. Neuron 1988;1:623-34.

19 Rokkas CK, Cronin CS, Nitta T, Helfrich, Jr LR, Lobner DC, Choi DW, Kouchoukos NT. Cardiopulmonary bypass, myocardial management, and support techniques. f Thorac Cardiovasc Surg 1995;110:27-35.

20 Reddy DVN, Rosenberg C, Kinsey VE. Steady state distribution of free amino acids in the aqueous humours, vitreous body and plasma of the rabbit. Exp Eye Res 1961; 1:175-81

21 Peachey NS, Green DJ, Ripps H. Ocular ischemia and the effects of allopurinol on functional recovery in the retina of the arterially perfused cat eye. Invest Ophthalmol Vis Sci 1993;34:58-65.

22 Nayak, MS, Kita M, Marmor MF. Protection of rabbit retina from ischemic injury by superoxide dismutase and catalase. Invest Ophthalmol Vis Sci 1993;34:2018-22.

23 Scheller MS, Zornow MH, Fleischer JE, Shearman GT, Greber TF. The noncompetitive N-methyl-D-aspartate receptor antagonist, MK-801 profoundly reduces volatile anesthetic requirements in rabbits. Neuropharmacom 1989; 28:677-81.

24 Michels RG. Postoperative management and complication. In: Michels RG, ed. Vitreous surgery. St Louis: CV Mosby, 1981:369-436. 